\title{
Effects of rain intensity and initial soil moisture on hydrological responses in laboratory conditions
}

\author{
Abdulvahed Khaledi Darvishan ${ }^{1}$, Kazimierz Banasik ${ }^{2 *}$, Seyed Hamidreza Sadeghi ${ }^{1}$, Leila Gholami ${ }^{3}$, \\ and Leszek Hejduk ${ }^{2}$ \\ ${ }^{1}$ Department of Watershed Management Engineering, Tarbiat Modares University (TMU), \\ P.O. Box 46414-356, Noor 46417-76489, Iran \\ ${ }^{2}$ Department of Water Engineering, Warsaw University of Life Sciences - SGGW, 02-787 Warsaw, Poland \\ ${ }^{3}$ Department of Watershed Management, Sari University of Agricultural Sciences and Natural Resources, P.O. Box 578, Sari, Iran
}

Received July 23, 2014; accepted February 9, 2015

\begin{abstract}
A b s t r a c t. Although the possibility of measuring and analysing all parts of the rainfall, infiltration, runoff, and erosion process as a natural hydrologic cycle in field conditions is still one of the more unattainable goals in the hydrological sciences, it can be accomplished in laboratory conditions as a way to understand the whole process. The initial moisture content is one of the most effective factors on soil infiltration, runoff, and erosion responses. The present research was conducted on a $2 \mathrm{~m}^{2}$ laboratory plot at a slope of $9 \%$ on a typical sandy-loam soil. The effects of the initial soil moisture content on the infiltration, runoff, and erosion processes were studied at four levels of initial soil moisture content $(12,25,33$, and 40 volumetric percentage) and two rainfall intensities (60 and $120 \mathrm{~mm} \mathrm{~h}^{-1}$ ). The results showed a significant $(p \leq 0.05)$ correlation between rainfall intensity and downstream splash, with $r=0.87$. The results reflected the theory of hydrological responses, showing significant $(\mathrm{p} \leq 0.05)$ correlations with $\mathrm{r}=-0.93,0.98,-0.83,0.88$, and 0.73 between the initial soil moisture content and the time-to-runoff, runoff coefficient, drainage as a part of the infiltrated water, downstream splash, and total outflow sediment, respectively.

$\mathrm{K}$ e y w o r d s: initial soil moisture, sandy loams, rainfall simulation, time-to-runoff, hydrological response
\end{abstract}

\section{INTRODUCTION}

Several interacting factors that control runoff generation determine the hydrological responses of the watershed to rainfall events (Castillo et al., 2003). Understanding the spatial and temporal variations of the main effective parameters on runoff and subsequent erosion, including infiltration, time-to-runoff and runoff coefficient, drainage, erosion and sediment yield, and knowing the critical condi-

*Corresponding author e-mail: kazimierz_banasik@sggw.pl tions leading to the production of increased runoff and more sediment is essential for better sediment yield prediction, model development, and land management (Banasik et al., 2012; Hejduk et al., 2006; Kovar et al., 2012; Krajewski et al., 2014; Madeyski and Banasik, 1989; Rejman et al., 2008). However, the measurement and analysis of all parts of the rainfall, infiltration, runoff, and erosion processes, as a natural hydrologic cycle in the field conditions, are some of the more unattainable goals in the hydrological sciences (Boomer et al., 2008; Rejman et al., 1999). To address this deficiency, simulated rainfalls and laboratory erosion plots are used to understand more about the whole process (Bashari et al., 2013; Defersha and Melesse, 2012; Fox and Bryan, 1999; Hawke et al., 2006; Khaledi Darvishan et al., 2014; Watung et al., 1996).

The amount and intensity of rainfall, initial soil moisture, infiltration, drainage, runoff, splash, and erosion are some of the main factors affecting various parts of the hydrological processes. These factors can decrease or increase the risk of runoff and soil erosion, not only through individual effects, but also through both antagonistic and synergistic interactions. Splash, for example, may play a synergistic role in soil erosion by developing the surface seal, which in and of itself leads to a decreased surface infiltration rate and an increased runoff coefficient.

On the one hand, the initial soil moisture content is an important factor that controls the runoff during medium and low intensity storms (Castillo et al., 2003) and rainwash, and differs by 4-5 times in the full range of initial soil

(C) 2015 Institute of Agrophysics, Polish Academy of Sciences 
moisture content, from air-dried to near-saturated levels (Luk, 1985; Luk and Hamilton, 1986). On the other hand, rainfall intensity and erosivity are known to be important factors in controlling the runoff and soil erosion processes (Banasik et al., 2001, 2012; Wischmeier and Smith, 1978). Despite their important roles, the interactions between the effective factors, especially on all of the main variables of hydrologic responses, have rarely been studied. The aim of this study was to determine the interaction between the initial soil moisture content and the rainfall intensity under four levels of soil moisture content.

\section{MATERIALS AND METHODS}

The present study was conducted in the Water Centre Laboratory of the Warsaw University of Life Sciences - SGGW in Warsaw, Poland. A S12 MKII Advanced Hydrology Study System with a $2 \mathrm{~m}^{2}$ laboratory plot (Armfield, 1998) was used to achieve the study purposes. The rainfall subsystem of S12 MKII was changed to three BEX B3/8S24W nozzles at a height of $2 \mathrm{~m}$ above the plot in order to obtain the raindrop size distribution that is as similar as possible to natural raindrop distribution. Two study rainfall intensities of 60 and $120 \mathrm{~mm} \mathrm{~h}^{-1}$ were simulated using one and two spray nozzles, respectively. Tap water was used to simulate the rainfall. The average diameter of the simulated raindrops was about $1.70 \mathrm{~mm}$, and the kinetic energy of the simulated rainfall was $21.13 \mathrm{~J} \mathrm{~m}^{-2} \mathrm{~mm}^{-1}$. The spatial distribution of the rainfall intensity was tested by taking measurements of the rain amount at 15 points using small plastic cups over the $2 \mathrm{~m}^{2}$ plot area. The collected rain amount data were then used in the Christiansen uniformity formula (Abudi et al., 2012; Battany and Grismer,
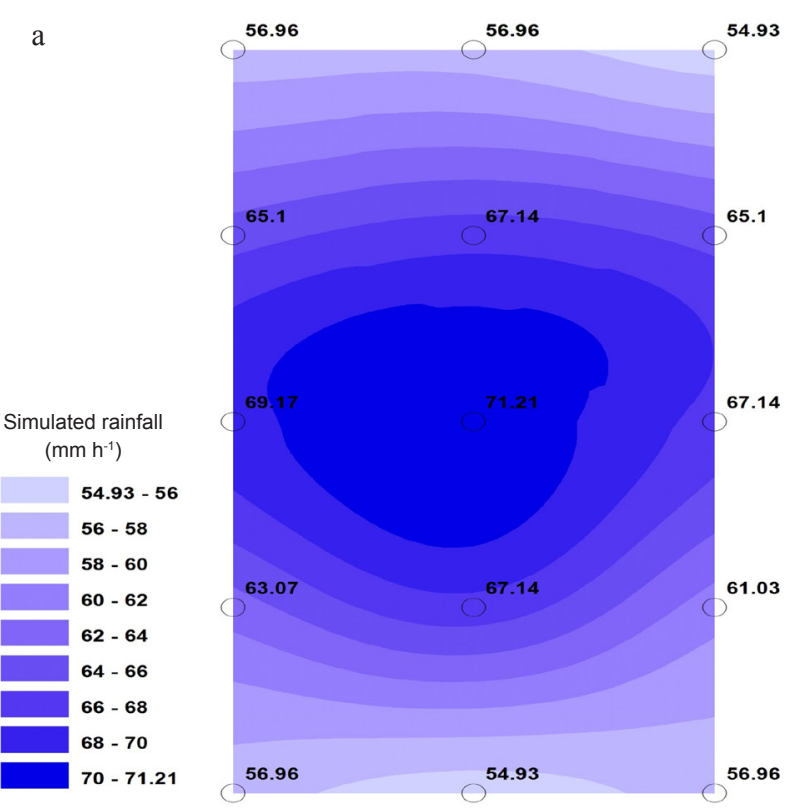

2000). The spatial distribution of the rainfall intensity over the study area is shown in Fig. 1. Due to the appropriate uniformity of the rainfall intensity and the relative homogeneity of the prepared soil as well as the time limitations in short sabbatical research, a methodology, including an experimental group without repetition, was considered.

The experiments were conducted on sandy-loam soil ( $12.6 \%$ clay, $30.8 \%$ silt, and $56.6 \%$ sand) that had a granular structure. The studied soil was taken from the top $0-50 \mathrm{~cm}$ layer (Kukal and Sarkar, 2010) of a deforested land, $15 \mathrm{~km}$ west of Warsaw, Poland. The particle size distribution of the soil studied by laser diffraction using the Mastersizer 2000 Ver. 5.60 instrument is shown in Fig. 2.

Bulk density, $\mathrm{pH}, \mathrm{EC}$, and organic content of the soil 'in situ' were measured as $1.67 \mathrm{~g} \mathrm{~cm}^{-3}, 6.73,124 \mu$ mohs cm $\mathrm{cm}^{-1}$, and $2.76 \%$, respectively. The soil was then prepared for laboratory simulation following Kukal and Sarkar method (2011). A $4 \mathrm{~mm}$ sieve was used to separate small pebbles after air-drying the soil (Agassi and Bradford, 1999; Defersha et al., 2011). A $5 \mathrm{~cm}$ layer of artificial pumice and course sand was used as a subsoil drainage layer with a filter structure (Darboux et al., 2001; Defersha et al., 2011). Finally, the main $7-\mathrm{cm}$ soil layer was placed over the drainage layer in the $2 \mathrm{~m}^{2}$ plot. A small hand ruler was then used to increase the bulk density of the soil so the soil was as similar as possible to that in the original field condition.

Two rainfall intensities of 60 and $120 \mathrm{~mm} \mathrm{~h}^{-1}$ had an optimised duration of 14 min after time-to-runoff. In addition, the treatments involved four initial soil moisture contents of $12(\approx$ air dried), 25 ( $\approx$ field capacity), 33, and $40(\approx$ near saturation) volumetric percentages, with a $9 \%$

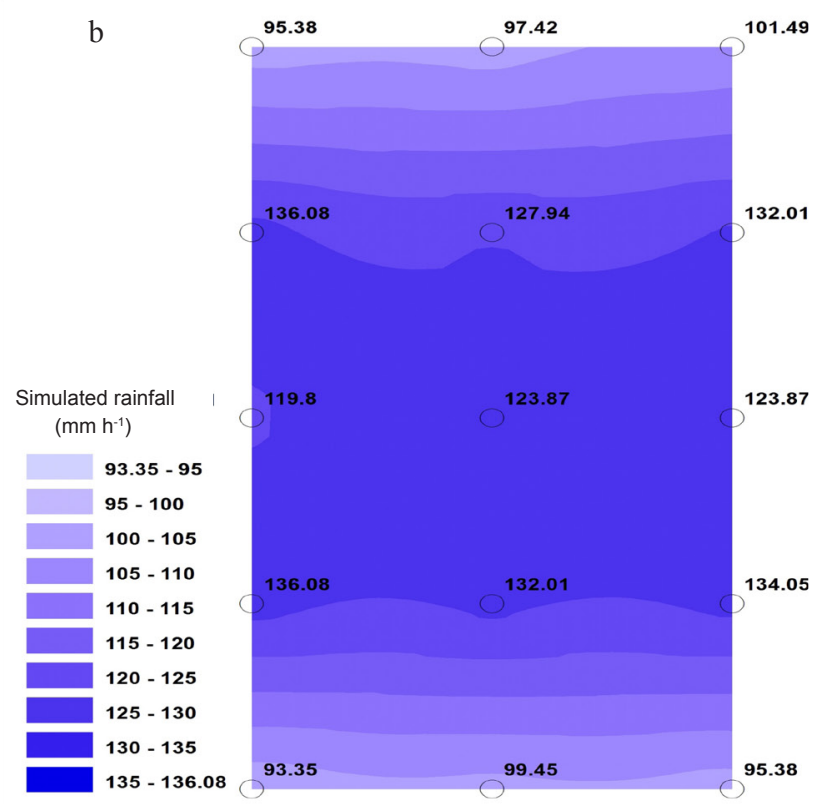

Fig. 1. Spatial distribution of rainfall intensity over the study area: $\mathrm{a}-60, \mathrm{~b}-120 \mathrm{~mm} \mathrm{~h}^{-1}$. 


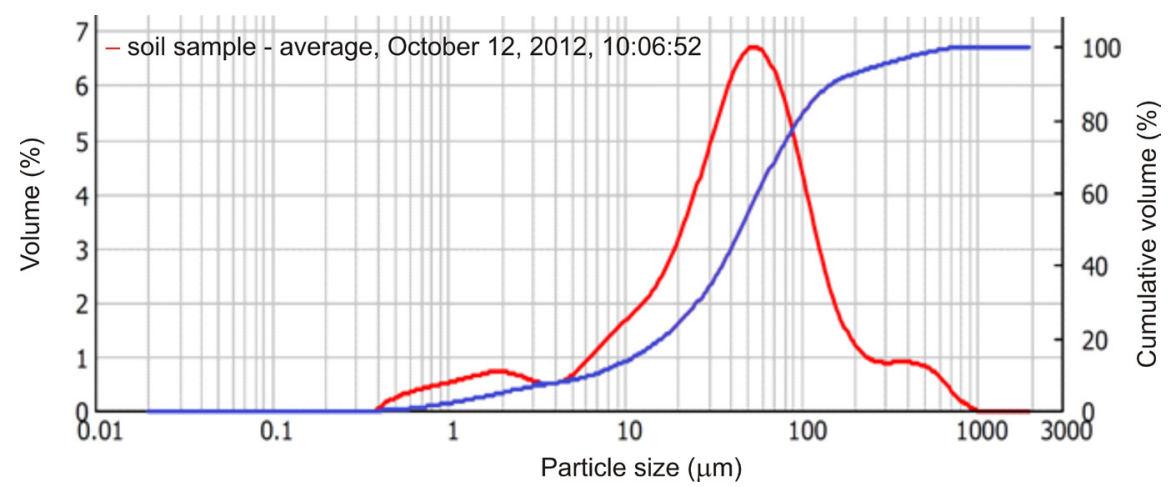

Fig. 2. Particle size distribution of the studied soil.

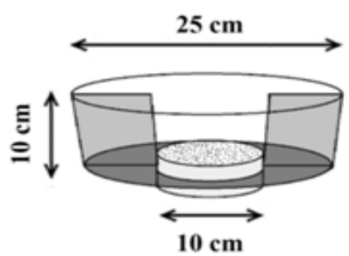

Fig. 3. Designed splash cup.

T a b l e 1. Treatment levels

\begin{tabular}{ccc}
\hline Treatment code & $\begin{array}{c}\text { Rainfall } \\
\text { intensity } \\
\left(\mathrm{mm} \mathrm{h}^{-1}\right)\end{array}$ & $\begin{array}{c}\text { Initial soil moisture } \\
(\text { volumetric \%) }\end{array}$ \\
\hline $60-12$ & & 12 \\
$60-25$ & 60 & 25 \\
$60-33$ & & 33 \\
$60-40$ & & 40 \\
$120-12$ & & 12 \\
$120-25$ & 120 & 25 \\
$120-33$ & & 33 \\
$120-40$ & & 40 \\
\hline
\end{tabular}

slope. The procedure used to determine the four levels of initial soil moisture involved having a relatively complete range of soil moisture, from air dried to near saturation.

In order to measure the amount of splash erosion induced by the raindrops in both the upslope and downslope directions, one splash cup (Khaledi Darvishan et al., 2014; Morgan, 1978) was placed in the centre of the experimental plot. The designed splash cup is shown in Fig. 3.

A total of eight experiments, including two levels of rainfall intensity and four levels of initial soil moisture content (Table 1), were conducted in this study. A $2 \mathrm{~cm}$ top layer of the soil was removed and then replaced before each experiment in order to prevent or decrease the effects of the previous splash and surface seals on the results. The $5 \mathrm{~cm}$ layer of remaining soil was given at least one day to reach the balance optimum moisture and remove the unwanted effects of water content for the subsequent experiments. Each level of soil moisture was then obtained through non-erosive small raindrops (spray raindrops), while simultaneously controlling the soil moisture.

The time-to-runoff in each experiment was recorded precisely when the first drops of runoff were found at the outlet of plot. The amount of runoff was then collected in two-minute intervals for $14 \mathrm{~min}$ after the time-to-runoff measurement began. The suspended sediment concentration (SSC) for all of the samples and the amount soil particles splashed in both the up and down directions in the splash cup were determined using settling, decantation, and drying methods (Gholami et al., 2013; Walling et al., 2001). In this procedure, the water layer that was over the settled suspended sediment was decanted after a $24 \mathrm{~h}$ period for settling the sediment in a sample with a volume of $200 \mathrm{ml}$. The settled sediment was then washed by distilled water into pre-weighed aluminium foil dishes, before oven drying at $105^{\circ} \mathrm{C}$ for $24 \mathrm{~h}$ (Gholami et al., 2013; Sadeghi et al., 2008).

The total amount of water that was infiltrated into the soil was calculated by subtracting the total amount of runoff from the total amount of rainfall. Next, the infiltration coefficient was calculated as a ratio between the total infiltrated water and the total amount of rainfall. The time-to-drainage was then recorded as the elapsed time from the first drop that flowed from drainage pipe at the end of the plot. The drainage coefficient was calculated as the ratio of the total amounts of drained and infiltrated water.

Determining the effects of rainfall intensity and initial soil moisture content after equalising the various running times for all of the experiments was necessary because of the various time-to-runoff values in order to remove the unwanted effects of rainfall duration. In other words, due to the undeniable effects of rainfall duration on runoff and soil loss, equalisation of running time was necessary in all experiments. The shortest time-to-runoff was added to a value of $14 \mathrm{~min}$ to determine the base rainfall duration. 
Following this, all other experiments were equalised with the same base rainfall duration by removing some samples from the end of data sets.

The collected data were analyzed using SPSS software (SPSS Inc. Released, 2009) to determine the correlation coefficients and significant effects. The one-way ANOVA test was also used to study the effects of rainfall intensity and initial soil moisture as independent factors on infiltration, runoff, drainage, erosion, and sediment. The collected data for all eight experiments are shown in Table 2. According to Table 2, the runoff threshold and infiltration coefficient were decreased and the runoff coefficient, downstream splash, and total sediment were increased with increasing rain intensity. The Spearman-Rho correlation coefficient was used to estimate the correlations between the quantitative characteristics of runoff, infiltration, and sediment production (Seeger, 2007), which are shown in Table 3. The Duncan test $(\alpha=0.05)$ was used to separate the homogenous subsets of initial soil moisture levels, which are shown in Table 4.

\section{RESULTS AND DISCUSSION}

The results showed significant $(p \leq 0.05)$ correlation coefficients of 0.87 between rainfall intensity and downstream splash $\left(\mathrm{g} \mathrm{m}^{-2}\right)$, and $-0.93,0.98,-0.83,0.88$ and 0.73 between the initial soil moisture content and the time-torunoff (s), runoff coefficient (\%), drainage as a part of infiltrated water $(\%)$, downstream splash $\left(\mathrm{g} \mathrm{m}^{-2}\right)$ and total outflow sediment $(\mathrm{g})$, respectively (Table 3 ). In the case of interactions between rainfall intensity and initial soil moisture, the results showed an antagonistic effect on the time-to-runoff and the suspended sediment concentration and a synergistic effect on downstream splash and total outflow sediment.

The relationships between the initial soil moisture content and all of the studied parameters, including downstream splash, infiltration coefficient, time-to-runoff, runoff coefficient, time-to-drainage and drainage coefficient, average suspended sediment concentration, and total outflow sediment in the various rainfall intensities are shown in Fig. 4.

Supporting the theory of hydrological processes, the results of this study demonstrated that in the rainfall intensities of 60 and $120 \mathrm{~mm} \mathrm{~h}^{-1}$, the initial soil moisture content affected the hydrological responses. However, the results of Castillo et al. (2003) differ from our findings, as Castillo et al. found that the hydrological response after high intensity storms is independent of the initial soil moisture content. Although some differences might exist because of different soil and laboratory conditions, such as drop size distribution and kinetic energy of simulated rainfalls, in the first minutes of the rainfall events, the effect of initial soil moisture content on hydrological responses was significant, even with high rainfall intensities. In addition to some individual effects of rainfall intensity and initial soil moisture content on infiltration, runoff, drainage, and erosion processes, there are some interaction effects that have the ability to increase or decrease the rates of individual effects. The results of separating homogenous subsets of initial soil moisture levels are shown in Table 4. The statistical results regarding the effects of rainfall intensity and initial soil moisture on infiltration, runoff, drainage, erosion, and sediment are shown in Tables 5 and 6, respectively.

T a b l e 2. Collected data for all eight experiments

\begin{tabular}{|c|c|c|c|c|c|c|c|c|c|c|}
\hline 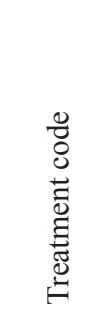 & 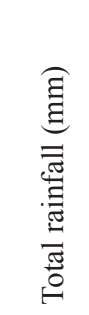 & 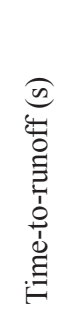 & 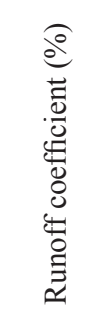 & 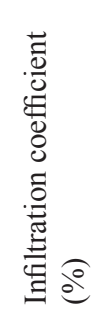 & 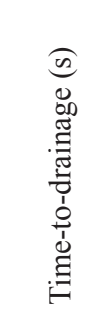 & 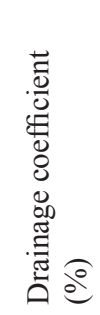 & 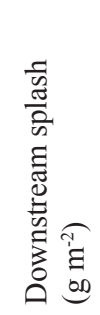 & 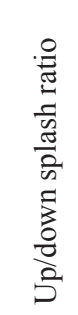 & 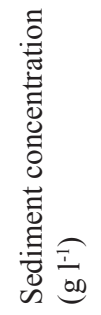 & 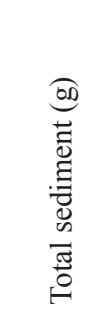 \\
\hline $60-12$ & 14.40 & 285 & 11.68 & 88.32 & 974 & 27.32 & 20.55 & 0.35 & 1.22 & 6.04 \\
\hline $60-25$ & 14.40 & 89 & 53.39 & 46.61 & 685 & 32.18 & 23.70 & 0.43 & 2.30 & 37.23 \\
\hline $60-33$ & 14.40 & 33 & 64.42 & 35.58 & 634 & 25.18 & 31.52 & 0.43 & 4.23 & 78.25 \\
\hline $60-40$ & 14.40 & 24 & 68.99 & 31.01 & 1090 & 20.49 & 35.67 & 0.42 & 4.09 & 81.41 \\
\hline $120-12$ & 28.47 & 184 & 31.05 & 68.95 & 565 & 30.26 & 64.81 & 0.40 & 3.14 & 59.26 \\
\hline $120-25$ & 28.47 & 64 & 56.26 & 43.74 & 382 & 25.58 & 74.61 & 0.40 & 3.76 & 127.40 \\
\hline $120-33$ & 28.47 & 23 & 68.19 & 31.81 & 697 & 26.34 & 89.50 & 0.43 & 3.94 & 155.42 \\
\hline $120-40$ & 28.47 & 14 & 77.56 & 22.44 & 1393 & 16.60 & 92.99 & 0.43 & 4.35 & 192.53 \\
\hline
\end{tabular}


T a b l e 3. Spearman-Rho correlation coefficients between the studied factors

\begin{tabular}{|c|c|c|c|c|c|c|c|c|c|}
\hline Factors & 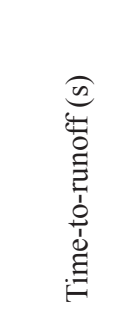 & 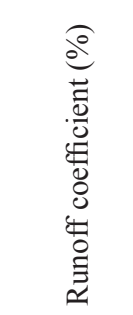 & 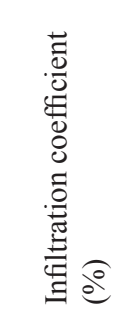 & 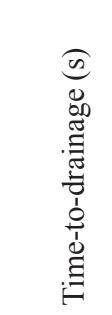 & 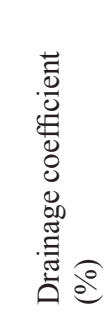 & 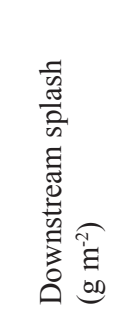 & 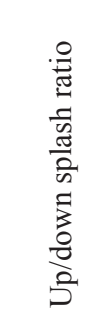 & 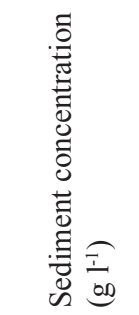 & 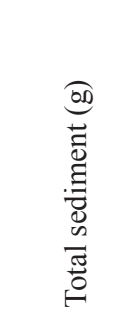 \\
\hline $\begin{array}{l}\text { Rainfall intensity } \\
\left(\mathrm{mm} \mathrm{h}^{-1}\right)\end{array}$ & & & & & & & & & \\
\hline $\begin{array}{l}\text { Rainfall duration } \\
\text { (s) Total rainfall } \\
(\mathrm{mm})\end{array}$ & -0.327 & 0.218 & -0.218 & -0.218 & -0.109 & $.873 * *$ & 0 & 0.218 & 0.655 \\
\hline $\begin{array}{l}\text { Initial soil } \\
\text { moisture (\%) }\end{array}$ & $-0.927 * *$ & $0.976^{* *}$ & $-0.976 * *$ & 0.586 & $-0.830^{*}$ & 0.488 & 0.654 & $0.878 * *$ & $0.732 *$ \\
\hline Time-to-runoff (s) & 1 & $-0.976^{* *}$ & $0.976 * *$ & -0.476 & $0.762 *$ & $-0.738^{*}$ & -0.702 & $-0.881 * *$ & $-0.905 * *$ \\
\hline $\begin{array}{l}\text { Runoff coefficient } \\
(\%)\end{array}$ & & 1 & $-1.00 * *$ & 0.524 & $-0.833^{*}$ & 0.667 & 0.639 & $0.905 * *$ & $0.857 * *$ \\
\hline $\begin{array}{l}\text { Infiltration } \\
\text { coefficient (\%) }\end{array}$ & & & 1 & -0.524 & $0.833^{*}$ & -0.667 & -0.639 & $-0.905^{* *}$ & $-0.857 * *$ \\
\hline $\begin{array}{l}\text { Time-to-drainage } \\
\text { (s) }\end{array}$ & & & & 1 & -0.476 & 0.095 & 0.243 & 0.333 & 0.238 \\
\hline $\begin{array}{l}\text { Drainage } \\
\text { coefficient (\%) }\end{array}$ & & & & & 1 & -0.5 & -0.255 & $-0.881 * *$ & $-0.714 *$ \\
\hline $\begin{array}{l}\text { Downstream } \\
\text { splash }\left(\mathrm{g} \mathrm{m}^{-2}\right)\end{array}$ & & & & & & 1 & 0.319 & 0.619 & $0.929 * *$ \\
\hline $\begin{array}{l}\text { Up/down splash } \\
\text { ratio }\end{array}$ & & & & & & & 1 & 0.6 & 0.46 \\
\hline $\begin{array}{l}\text { Sediment } \\
\text { concentration } \\
\left(\mathrm{g} \mathrm{l}^{-1}\right)\end{array}$ & & & & & & & & 1 & $0.786^{*}$ \\
\hline Total sediment (g) & & & & & & & & & 1 \\
\hline
\end{tabular}

Significant at the level: $* 0.05, * * 0.01$.

The results of separating homogenous subsets in the treatment levels showed that, in the case of runoff and infiltration, there are two groups of homogenous initial soil moisture levels: the lowest level $(12 \%)$ and the other levels $(25,33$ and $44 \%)$. This means that there is a more significant difference between the initial soil moisture content of $12 \%$ and the other studied levels $(25,33$ and $44 \%)$. Nevertheless, all levels of initial soil moisture were in one subset group when their effects were considered relative to the erosion and sediment parameters.

The effects of rainfall intensity on the downstream splash and total outflow sediment were significant $(p \leq 0.05$ and $p \leq 0.01$ respectively). Regarding the initial soil moisture content, the effects on the infiltration coefficient, time-to-runoff, and runoff coefficient were also significant $(p \leq 0.01, p \leq 0.05$, and $p \leq 0.01$ respectively). The best linear regression models to estimate the studied processes were found using SPSS and are shown in Table 7. Three factors of rainfall intensity, the total rainfall, and the initial soil moisture were considered as independent variables, but the rainfall intensity was then automatically removed with the Enter method of the regression process. The standardized coefficients $(\beta)$ in linear regression models were used to prioritise the factors affecting the infiltration, runoff, drainage, erosion, and sediment parameters (Vahabi and Mahdian, 2009). According to this method, a higher beta coefficient indicates a greater effect (Table 8 ). 
T a b l e 4. Homogenous subsets of initial soil moisture levels using the Duncan test $(\alpha=0.05)$

Effective factor $=$ initial soil moisture

Homogenous subsets

\begin{tabular}{lcc} 
& 1 & 2 \\
\hline Infiltration coefficient (\%) & $25,33,40$ & 12 \\
Time-to-runoff (s) & $25,33,40$ & $25,33,40$ \\
Runoff coefficient (\%) & 12 & $12,33,40$ \\
Time-to-drainage (s) & $12,25,33$ & $12,25,33$ \\
Drainage coefficient (\%) & 33,40 & - \\
Downstream splash (g m $\left.{ }^{-2}\right)$ & $12,25,33,40$ & - \\
Up/down splash ratio & $12,25,33,40$ & - \\
$\begin{array}{l}\text { Average suspended sediment } \\
\text { concentration (g } \mathrm{l}^{-1} \text { ) }\end{array}$ & $12,25,33,40$ & - \\
Total outflow sediment (g) & $12,25,33,40$ &
\end{tabular}

a

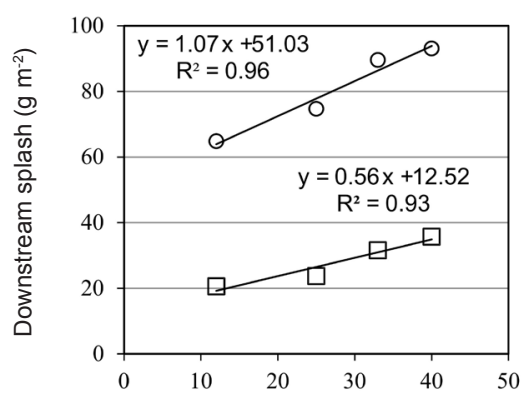

c
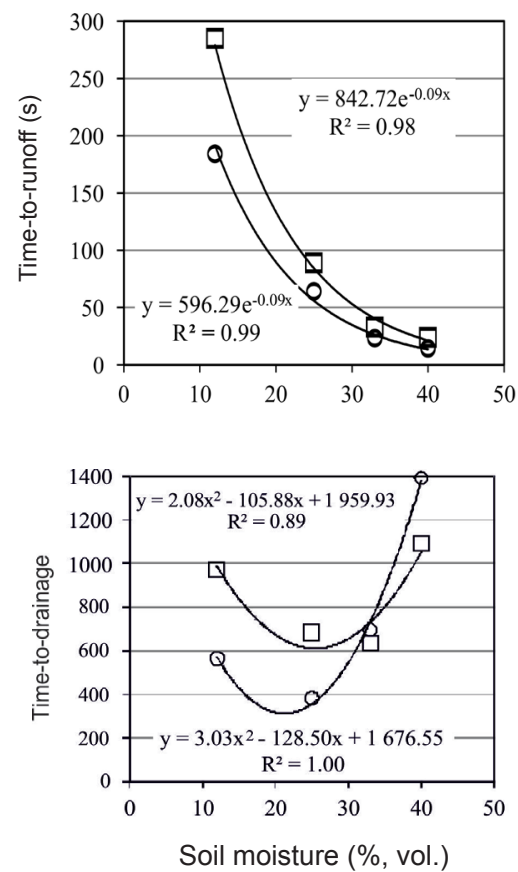

b

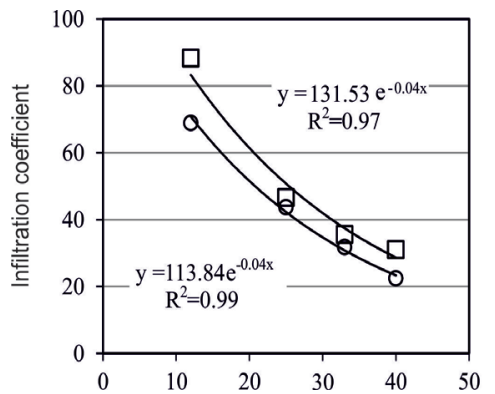

d

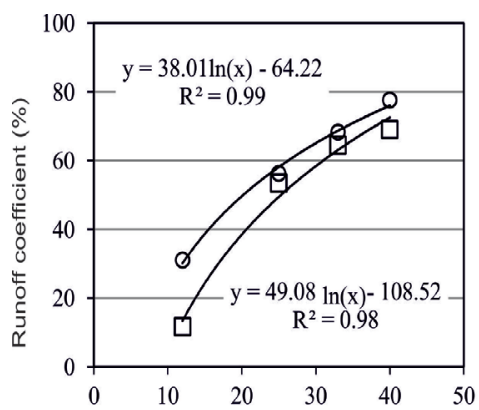

f

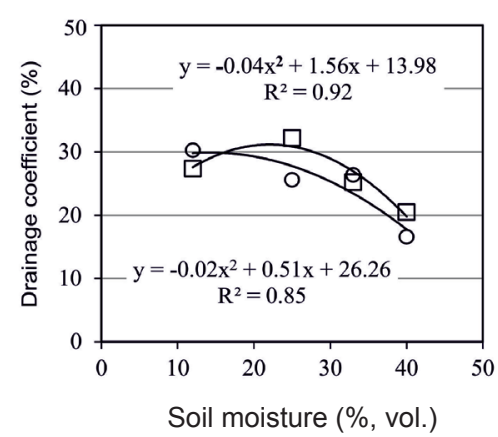

Fig. 4. Relationship between initial soil moisture and: a - downstream splash, b - infiltration coefficient, c - time-to-runoff, $d$ - runoff coefficient, e - time-to-drainage, $\mathrm{f}$ - drainage coefficient, $\mathrm{g}$ - average sediment concentration, $\mathrm{h}$ - total outflow sediment; for rainfall intensity of $60 \mathrm{~mm} \mathrm{~h}^{-1}$ (squares) and $120 \mathrm{~mm} \mathrm{~h}^{-1}$ (circles). 
g

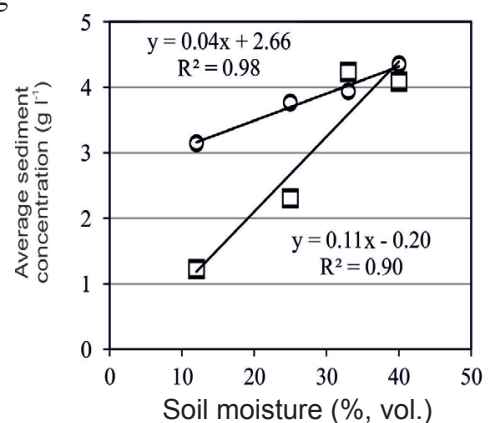

$\mathrm{h}$

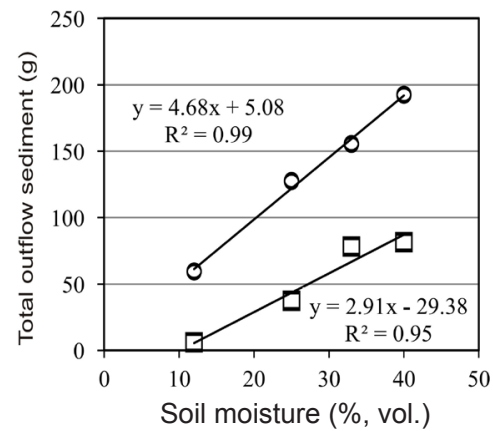

Fig. 4. Continuation.

T a b l e 5. Results of the one-way ANOVA test to determine the effects of rainfall intensity on infiltration, runoff, drainage, erosion, and sediment

\begin{tabular}{|c|c|c|c|c|}
\hline Hydrological responses & Sum of squares & Degrees of freedom & F-ratio & Significance of $F$ \\
\hline Infiltration coefficient $(\%)$ & 149.47 & 1 & 0.275 & 0.619 \\
\hline Time-to-runoff (s) & 2664.50 & 1 & 0.255 & 0.632 \\
\hline Runoff coefficient (\%) & 149.47 & 1 & 0.275 & 0.619 \\
\hline Time-to-drainage (s) & 14964.50 & 1 & 0.123 & 0.738 \\
\hline Drainage coefficient $(\%)$ & 5.10 & 1 & 0.179 & 0.687 \\
\hline Downstream splash $\left(\mathrm{g} \mathrm{m}^{-2}\right)$ & 5537.20 & 1 & 50.110 & 0.000 \\
\hline Up/down splash ratio & 0.00 & 1 & 0.126 & 0.735 \\
\hline $\begin{array}{l}\text { Average suspended sediment } \\
\text { concentration }\left(\mathrm{g} \mathrm{l}^{-1}\right)\end{array}$ & 1.40 & 1 & 1.183 & 0.318 \\
\hline Total outflow sediment (g) & 13751.45 & 1 & 6.161 & 0.048 \\
\hline
\end{tabular}

T a b l e 6. Results of the one-way ANOVA test to determine the effects of initial soil moisture on infiltration, runoff, drainage, erosion, and sediment

\begin{tabular}{|c|c|c|c|c|}
\hline Hydrological responses & Sum of squares & Degrees of freedom & F-ratio & Significance of $F$ \\
\hline Infiltration coefficient $(\%)$ & 3177.30 & 3 & 17.985 & 0.009 \\
\hline Time-to-runoff (s) & 59893.00 & 3 & 14.485 & 0.013 \\
\hline Runoff coefficient (\%) & 3177.30 & 3 & 17.985 & 0.009 \\
\hline Time-to-drainage (s) & 569880.00 & 3 & 4.282 & 0.097 \\
\hline Drainage coefficient (\%) & 141.37 & 3 & 5.489 & 0.067 \\
\hline Downstream splash $\left(\mathrm{g} \mathrm{m}^{-2}\right)$ & 601.18 & 3 & 0.143 & 0.929 \\
\hline Up/down splash ratio & 0.00 & 3 & 2.848 & 0.169 \\
\hline $\begin{array}{l}\text { Average suspended sediment } \\
\text { concentration }\left(\mathrm{g} \mathrm{l}^{-1}\right)\end{array}$ & 5.53 & 3 & 2.470 & 0.201 \\
\hline Total outflow sediment $(\mathrm{g})$ & 12510.30 & 3 & 1.140 & 0.434 \\
\hline
\end{tabular}


T a b l e 7. The best linear regression models to estimate the studied parameters

\begin{tabular}{|c|c|c|c|}
\hline Models & $\mathrm{R}^{2}$ & Adj. $R^{2}$ & $\begin{array}{l}\text { Std. error } \\
\text { of estimate }\end{array}$ \\
\hline Infiltration coefficient $=-1.876$ IniSoilM -0.614 TotRain +110.823 & 0.937 & 0.912 & 6.557 \\
\hline Time-to-runoff $=-7.932$ IniSoilM -2.594 TotRain +363.233 & 0.874 & 0.823 & 40.639 \\
\hline Runoff coefficient $=1.876$ IniSoilM +0.614 TotRain -10.823 & 0.937 & 0.912 & 6.557 \\
\hline Time-to-drainage $=13.667$ IniSoilM -6.148 TotRain +558.624 & 0.236 & -0.069 & 337.811 \\
\hline Drainage coefficient $=-0.335$ IniSoilM -0.114 TotRain +37.133 & 0.581 & 0.414 & 3.836 \\
\hline Downstream splash $=0.814$ IniSoilM +3.740 TotRain -48.379 & 0.986 & 0.980 & 4.220 \\
\hline Up/down splash ratio $=0.002$ IniSoilM +0.001 TotRain +0.347 & 0.597 & 0.436 & 0.021 \\
\hline $\mathrm{SSC}=0.087$ IniSoilM +0.060 TotRain -0.047 & 0.786 & 0.701 & 0.603 \\
\hline Total sediment $=3.794$ IniSoilM +5.893 TotRain -138.471 & 0.966 & 0.952 & 13.604 \\
\hline
\end{tabular}

IniSoilM - initial soil moisture (\%), TotRain - total rainfall (mm).

According to Table 8, the effects of the initial soil moisture on infiltration, runoff, and drainage parameters were more significant than the effects of rainfall in terms of downstream splash and total outflow sediment. In addition, regarding the suspended sediment concentration, the strong effect of the initial soil moisture content on the runoff volume might be the main reason for its significance.

T a b l e 8. Standardized coefficients $(\beta)$ in linear regression models

\begin{tabular}{|c|c|c|}
\hline \multirow{2}{*}{ Parameter } & \multicolumn{2}{|c|}{$\begin{array}{c}\text { Standardized coefficients } \\
\text { Beta }(\beta)\end{array}$} \\
\hline & $\begin{array}{l}\text { Initial soil } \\
\text { moisture }(\%)\end{array}$ & $\begin{array}{l}\text { Total rainfall } \\
(\mathrm{mm})\end{array}$ \\
\hline Infiltration coefficient $(\%)$ & -0.945 & -0.209 \\
\hline Time-to-runoff (s) & -0.913 & -0.202 \\
\hline Runoff coefficient (\%) & 0.945 & 0.209 \\
\hline Time-to-drainage (s) & 0.465 & -0.142 \\
\hline Drainage coefficient (\%) & -0.743 & -0.170 \\
\hline Downstream splash $\left(\mathrm{g} \mathrm{m}^{-2}\right)$ & 0.304 & 0.945 \\
\hline Up/down splash ratio & 0.759 & 0.143 \\
\hline $\begin{array}{l}\text { Suspended sediment } \\
\text { concentration }\left(\mathrm{g} \mathrm{l}^{-1}\right)\end{array}$ & 0.788 & 0.406 \\
\hline Total outflow sediment (g) & 0.678 & 0.712 \\
\hline
\end{tabular}

\section{CONCLUSIONS}

1. The effects of rainfall intensity and initial soil moisture on various parts of the infiltration, runoff, and erosion processes are not the same. The rainfall intensity was the dominant factor influencing the splash erosion and outflow sediment, while initial soil moisture content was the dominant factor for infiltration and runoff.

2. Regarding the interactions between rainfall intensity and initial soil moisture, the results demonstrated an antagonistic effect on the time-to-runoff and the suspended sediment concentration as well as a synergistic effect on the downstream splash and total outflow sediment.

3 . Although the results were in agreement with the theory of hydrological responses, due to the large differences between the field and laboratory conditions, especially in terms of soil structure, it is highly recommended that the same research framework be used in field plots using portable rainfall simulators and more rainfall intensity levels.

\section{ACKNOWLEDGMENT}

The authors would like to thank to A. Brandyk, A. Baryła and D. Górski for their assistance in coordinating with the Water Centre Laboratory. They would also like to thank Z. Pietraszek for his technical assistance with the nozzles and rainfall simulations; J. Gładecki and M. Mackiewicz for their ongoing assistance with the preparation of the soil and other materials in the laboratory and administrative works. The laboratory investigations were conducted at the Water Center Laboratory of Warsaw University of Life Sciences - SGGW during A. Khaledi Darvishan and L. Gholami six-month research stay at the Department of Water Engineering at the Warsaw University of Life Sciences, and have been partly supported by PL-NCN as part of research project NN305 396238. The support provided by the organization is gratefully acknowledged. 


\section{REFERENCES}

Abudi I., Carmi G., and Berliner P., 2012. Rainfall simulator for field runoff studies. J. Hydrol., 454-455, 76-81.

Agassi M. and Bradford J.M., 1999. Methodologies for interrill soil erosion studies. Soil Till. Res., 49, 277-287.

Armfield, 1998. Advanced Hydrology System S12 MkII Instruction. Armfield Ltd., Ringwood, UK.

Banasik K., Gorski D., and Mitchell J.K., 2001. Rainfall erosivity for east and central Poland. Proc. Int. Symp. Soil Erosion Research for the 21st Century. January 3-5, Honolulu, HI, USA.

Banasik K., Gorski D., Popek Z., and Hejduk L., 2012. Estimating the annual sediment yield of a small agricultural catchment in central Poland. In: Erosion and Sediment Yields in the Changing Environment (Eds A.E. Collins, V. Golosov, A.J. Horowitz, X. Lu, M. Stone, D.E. Walling, and X. Zhang). IAHS Press, Wallingford, UK.

Bashari M., Moradi H.R., Kheirkhah M.M., and JafariKhaledi M., 2013. Temporal variations of runoff and sediment in different soil clay contents using simulated conditions. Soil Water Res., 8(3), 124-132.

Battany M.C. and Grismer M.E., 2000. Development of a portable field rainfall simulator for use in hillside vineyard runoff and erosion studies. Hydrological Proc., 14, 1119-1129.

Boomer K.B., Weller D.E., and Jordan T.E., 2008. Empirical models based on the universal soil loss equation fail to predict sediment discharges from chesapeake bay catchments. J. Environ. Qual., 37, 79-89.

Castillo V.M., Gomez-Plaza A., and Martinez-Mena M., 2003. The role of antecedent soil water content in the runoff response of semiarid catchments: A simulation approach. J. Hydrol., 284, 114-130.

Darboux F., Davy P.H., Gascuel-Odoux C., and Huang C., 2001. Evolution of soil surface roughness and flowpath connectivity in overland flow experiments. Catena, 46, 125-139.

Defersha M.B. and Mellese A.M., 2012. Effect of rainfall intensity, slope and antecedent moisture content on sediment concentration and sediment enrichment ratio. Catena, 90, 47-52.

Defersha M.B., Quraishi S., and Mellese A.M., 2011. The effect of slope steepness and antecedent moisture content on interrill erosion, runoff and sediment size distribution in the highlands of Ethiopia. Hydrology Earth System Sci., 15, 2367-2375.

Fox D.M. and Bryan R.B., 1999. The relationship of soil loss by interrill erosion to slope gradient. Catena, 38, 211-222.

Gholami L., Sadeghi S.H.R., and Homaee M., 2013. Straw mulching effect on splash erosion, runoff, and sediment yield from eroded plots. Soil Sci. Soc. Am. J., 77, 268-278.

Hawke R.M., Price A.G., and Bryan R.B., 2006. The effect of initial soil water content and rainfall intensity on near-surface soil hydrologic conductivity: A laboratory investigation. Catena, 65, 237-246.

Hejduk L., Hejduk A., and Banasik K., 2006. Suspended sediment transport during rainfall and snowmelt-rainfall floods in a small lowland catchment, central Poland. In: Soil Erosion and Sediment Redistribution in River Catchments (Eds P.N. Owens, A.J. Collins), CABI Publishing, Wallingford, UK.

Khaledi Darvishan A., Sadeghi S.H.R., Homaee M., and Arabkhedri M., 2014. Measuring sheet erosion using synthetic color-contrast aggregates. Hydrol. Proc., 28(15), 4463-4471.
Kovar P., Vassova D., and Janecek M., 2012. Surface runoff simulation to mitigate the impact of soil erosion, case study of Trebsin (Czech Republic). Soil Water Res., 7, 85-96.

Krajewski A., Lee H., Hejduk L., and Banasik K., 2014. Predicting small catchment responses to heavy rainfalls with SEGMO and two sets of model parameters. Annals of Warsaw University of Life Sciences - SGGW, Land Reclamation, 46(3), 205-220.

Kukal S.S. and Sarkar M., 2010. Splash erosion and infiltration in relation to mulching and polyviny1 alcohol application in semi-arid tropics. Archives Agron. Soil Sci., 56(6), 697-705.

Kukal S.S. and Srakar M., 2011. Laboratory simulation studies on splash erosion and crusting in relation to surface roughness and raindrop size. J. Indian Soc. Soil Sci., 59(1), 87-93.

Luk S.H., 1985. Effect of antecedent soil moisture content on rainwash erosion. Catena, 12, 129-139.

Luk S.H. and Hamilton H., 1986. Experimental effects of antecedent moisture and soil strength on rainwash erosion of two luvisols, Ontario. Geoderma, 37(1), 29-43.

Madeyski M. and Banasik K., 1989. Applicability of the modified universal soil loss equation in small Carpathian watersheds. Catena, 75-80.

Morgan R.P.C., 1978. Field studies of rainsplash erosion. Earth Surface Proc. Landforms, 3, 295-299.

Nanko K., Mizugaki S., and Onda Y., 2008. Estimation of soil splash detachment rates on the forest floor of an unmanaged Japanese cypress plantation based on field measurements of throughfall drop sizes and velocities. Catena, 72, 348-361.

Rejman J., Brodowski R., and Iglik I., 2008. Annual variations of soil erodibility of silt loam developed from loess based on 10-years runoff plot studies. Annals Warsaw University of Life Sciences - SGGW, Land Reclamation, 39, 77-83.

Rejman J., Usowicz B., and Dębicki R., 1999. Source of errors in predicting soil erodibility with the USLE. Polish J. Soil Sci., 32, 13-22.

Sadeghi S.H.R., Mizuyama T., Miyata S., Gomi T., Kosugi K., Fukushima T., Mizugaki S., and Onda Y., 2008. Determinant factors of sediment graphs and rating loops in a reforested watershed. J. Hydrol., 356, 271-282.

Seeger M., 2007. Uncertainty of factors determining runoff and erosion processes as quantified by rainfall simulations. Catena, 71, 56-67.

SPSS Inc. Released, 2009. PASW Statistics for Windows, Version 18.0. Chicago: SPSS Inc., USA.

Vahabi J. and Mahdian M.H., 2009. Investigating the effect of edaphic parameters on runoff using a rainfall simulator (in Persian). Watershed Manag. Res., 83, 10-20.

Walling D.E., Collins A.L., Sichingabula H.A., and Leeks G.J.L., 2001. Integrated assessment of catchment suspended sediment budgets: A Zambian example. Land Degrad. Dev., 12, 387-415.

Watung R.L., Sutherland R.A., and El-Swaify S.A., 1996. Influence of rainfall energy flux density and antecedent soil moisture content on splash transport and aggregate enrichment ratios for a Hawaiian oxisol. Soil Technol., 9, 251-272.

Wischmeier W.H. and Smith D.D., 1978. Predicting rainfall erosion losses. A guide to conservation planning. Agriculture Handbook. Department of Agriculture, Washington, DC, USA. 